\title{
Treatment of soybean seeds of different levels of physiological quality with amino acids ${ }^{1}$
}

\author{
Caio Sippel Dörr ${ }^{2 *}$, Tainan Lopes de Almeida², Luis Eduardo Panozzo ${ }^{2}$, \\ Luis Osmar Braga Schuch ${ }^{2}$
}

\begin{abstract}
The aim of this study was to assess the effect of seed treatment at different levels of physiological quality with amino acids on the performance of seeds and plants in the field. The experimental design was a randomized complete block design with four replications involving a combination of two factors. Factor A consisted of seed lots of three levels of physiological quality (high, intermediate, and low) and factor B consisted of five doses of a commercial product based on amino acids used in seed treatment.Seeds of different levels of physiological quality were treated with a commercial product (C.P.) at doses of 0, 200, 400, 600, and $800 \mathrm{~mL}$ C.P. $100 \mathrm{~kg}^{-1}$ of seeds. After seed treatment, the physiological performance was assessed in the laboratory and then the seeds were sowed in the field aiming at assessing plant performance, yield components, and productivity. Seed treatment with amino acids does not promote the physiological performance of seeds and plants in the field. The productivity of isolated soybean plants from seed lots of a high physiological quality is $15 \%$ higher than that of plants from seed lots of a low physiological quality.
\end{abstract}

Index terms: Glycine max, germination, seed vigor, productivity.

\section{Tratamento de sementes de soja de diferentes níveis de qualidade fisiológica com aminoácidos}

\begin{abstract}
RESUMO - O objetivo no presente trabalho foi avaliar o efeito do tratamento de sementes de diferentes níveis de qualidade fisiológica com aminoácidos, sobre o desempenho de sementes e plantas em campo. O delineamento experimental adotado foi o de blocos casualizados em esquema fatorial com quatro repetições, envolvendo a combinação de dois fatores. Sendo eles, fator A, lotes de sementes de três níveis de qualidade fisiológica (elevada, intermediária e reduzida), e fator B, cinco doses de produto comercial a base de aminoácidos utilizado em tratamento de sementes. As sementes de diferentes níveis de qualidade fisiológica foram tratadas com produto comercial (P.C.) a base de aminoácidos nas doses de 0, 200, 400, 600 , e $800 \mathrm{~mL}$ P.C. $100 \mathrm{~kg}^{-1}$ de sementes. Após o tratamento das sementes foi avaliado o desempenho fisiológico em laboratório e posteriormente, realizou-se a semeadura em campo para avaliação do desempenho das plantas, componentes do rendimento e produtividade. O tratamento de sementes com aminoácidos não promove acréscimos no desempenho fisiológico das sementes e de plantas em campo. A produtividade de plantas isoladas de soja oriundas de lotes de sementes de elevada qualidade fisiológica é $15 \%$ superior ao de plantas oriundas de lotes de sementes de qualidade fisiológica reduzida.
\end{abstract}

Termos para indexação: Glycine max, germinação, vigor de sementes, produtividade.

\section{Introduction}

The physiological quality of seeds and its effect on the performance of plants in the field is a topic that has often been discussed in scientific papers, highlighting the importance of its use (Tavares et al., 2013; Silva et al., 2013; Cantarelli et al., 2015). High physiological quality seeds promote a higher seedling resistance to environmental stresses, adequate plant stand density, higher initial growth, uniformity among plants, and increase of yield components and productivity as evidenced

\footnotetext{
${ }^{1}$ Submitted on $05 / 16 / 2018$. Accepted for publication on 08/22/2018.

${ }^{2}$ Programa de Pós-Graduação em Ciência e Tecnologia de Sementes, Universidade Federal de Pelotas, 96010-900 - Pelotas, RS, Brasil.

*Corresponding author <caiodorrcsd@gmail.com>
} 
in several studies with individual plants or in plant populations (Schereen et al., 2010; Mattioni et al., 2012; Tavares et al., 2013; Silva et al., 2013; Cantarelli et al., 2015). However, soybean seed lots of low physiological quality with high deterioration rates are often found being commercialized (Melo et al., 2016).

Thus, in the search for a better seed performance in the field, technologies associated with seed treatment have been developed in order to provide a higher vigor to seedlings (Kolling et al., 2016; Cunha et al., 2015; Abrecht et al., 2014; Brzezinski et al., 2015). An alternative that has been widely studied to improve the performance of seeds and plants in the field is the use of amino acids in different crops through different forms of application in order to promote plant growth and improve the quality of the harvested products (Ludwig et al., 2011; Bettoni et al., 2013; Hammad and Ali, 2014; Wang et al., 2014; Mondal et al., 2015).

The application of amino acids in several crops does not aim to supply the need for these amino acids for protein synthesis, but to activate the physiological metabolism of plants, being an important anti-stressing action. Some amino acids through their catabolism produce carbon chain compounds for the Krebs cycle, thus fueling the respiration and energy production processes in the plant (Hildebrandt et al., 2015). Others are precursors of plant hormones in plants, such as tryptophan,which is the precursor to indole acetic acid (IAA) (Taiz and Zeiger, 2013), and methionine, a precursor to ethylene (Hildebrandt et al., 2015).

Because of this, it is speculated that the application of amino acids via seed treatment can promote the performance of seeds and plants in the field. Therefore, the aim of this study was to assess the effect of seed treatment at different levels of physiological quality on the performance of seeds and plants in the field and their productivity.

\section{Material and Methods}

The study was developed at the Didactic Laboratory of Seed Testing and atan experimental area of the Faculdade Agronomia Eliseu Maciel, belonging to the Universidade Federal de Pelotas, located in Capão do Leão, $R S$, in the 2014/15 season.

The experimental design was a randomized complete block design with four replications involving a combination of two factors. Factor A consisted of seed lots of three levels of physiological quality (high, intermediate, and low) and factor B consisted of five doses of a commercial product based on amino acids used in seed treatment.

Three lots of soybean seeds of different levels of physiological quality of the cultivar BMX Potência RR were used. The different levels of physiological quality were obtained through the artificial aging of seeds of a lot of high physiological quality. High physiological quality seeds were artificially agedby remaining for 48 and $72 \mathrm{~h}$ at a temperature of $41{ }^{\circ} \mathrm{C}$ and relative humidity close to $100 \%$ to obtain the lots of intermediate and low physiological quality, respectively. After artificial aging, the seeds were dried in a forced air circulation oven at a temperature of $38{ }^{\circ} \mathrm{C}$ to a humidity of $12 \%$. Subsequently, the physiological quality of seeds was assessed through germination, first germination count, and accelerated aging tests. Regardless of the seed lot, in the accelerated aging test, the methodology was normally used as described.

The high physiological quality lot presented 94\% of germination, $82 \%$ of first germination count, and $95 \%$ of germination after accelerated aging. The intermediate physiological quality lot presented $95 \%$ of germination, $74 \%$ of first germination count, and $76 \%$ of germination after accelerated aging. The low physiological quality lot presented $88 \%$ of germination, $68 \%$ of first germination count, and $57 \%$ of germination after accelerated aging.

Seeds of different levels of physiological quality were treated with a commercial product (C.P.) at doses of 0,200 , 400,600 , and $800 \mathrm{~mL}$ C.P. $100 \mathrm{~kg}^{-1}$ of seeds. The product used is composed of the following amino acids and nutrients: alanine $(1.164 \%)$, arginine (0.189\%), aspartic acid (1.943\%), glutamic acid (3.316\%), glycine $(0.202 \%)$, isoleucine $(0.171 \%)$, leucine $(0.268 \%)$, lysine $(0.240 \%)$, phenylalanine $(0.143 \%)$, serine $(0.179 \%)$, threonine $(0.188 \%)$, tryptophan $(0.175 \%)$, tyrosine $(0.122 \%)$, valine $(0.288 \%)$, and the nutrients nitrogen $(11 \%)$ and potassium $\left(\mathrm{K}_{2} \mathrm{O}, 1 \%\right)$.

Seed treatment was carried out by placing the product with a graduated pipette directly in the bottom of polyethylene bags and spread on the sides of the bags up to $15 \mathrm{~cm}$ height. Afterward, $0.2 \mathrm{~kg}$ of seeds were added inside the polyethylene bag and both product and seeds were agitated for 3 minutes. The volume of solution used for seed treatment was $0.8 \mathrm{~L}$. $100 \mathrm{~kg}^{-1}$ of seeds, with distilled water to supplement the volume when necessary.For the zero dose, seeds were treated with distilled water in order to maintain the same conditions of seed moisture for all the tested treatments. Seeds were then placed to dry at ambient temperature for $24 \mathrm{~h}$. Prior to sowing in the pits, the seeds were treated with an inoculant at a dose of $2 \mathrm{~mL} \cdot \mathrm{kg}^{-1}$ of seeds.

After treatment, the physiological performance of seeds was assessed by the tests of germination, first germination count, cold, accelerated aging, and root and shoot length of the seedling.

Germination was carried out with four subsamples of 50 seeds for each experimental unit, which was placed on a 
germitest paper substrate previously moistened with distilled water using 2.5 times the mass of the dry paper as water weight and maintained at $25{ }^{\circ} \mathrm{C}$. The assessments were carried out at five and eight days after sowing, according to the Rules for Seed Testing (Brasil, 2009) and the results expressed as the percentage of normal seedlings. The first germination count consisted of determining the percentage of normal seedlings at five days after sowing and germination at eight days after sowing.

The cold test was conducted with four subsamples of 50 seeds for each experimental unit.The sowing was performed on a germitest paper substrate previously moistened with distilled water in the ratio of 2.5 times the mass of the dry paper. The prepared rolls were wrapped in plastic bags, sealed with adhesive tape, and maintained in a germination chamber (B.O.D) at $10{ }^{\circ} \mathrm{C}$ for seven days. At the end of this period, the rolls were removed from the plastic bags and brought to a germinator at $25{ }^{\circ} \mathrm{C}$ for five days, when the assessment was performed (Cícero and Vieira, 1994). The results were expressed as the percentage of normal seedlings, according to the criteria adopted for the germination test (Brasil, 2009).

Accelerated aging was performed using gerbox type boxes with horizontal metal screen fixed in the median position. A volume of $40 \mathrm{~mL}$ of distilled water was added to the bottom of each gerbox and the seeds were distributed on each screen to cover its surface and constitute a single layer. Then, the boxes containing the seeds were capped and conditioned in a BOD type incubator at $41{ }^{\circ} \mathrm{C}$, where they remained for 48 h (Marcos-Filho, 1999). After this period, the seeds were submitted to the germination test, as previously described.

Root and shoot length were carried out with four subsamples of 20 seeds for each experimental unit, which was sown on a germitest paper substrate previously moistened with distilled water using 2.5 times of the mass of the dry paper, and maintained in a germinator at $25{ }^{\circ} \mathrm{C}$ for five days (Nakagawa, 1999). A linewas drawn on the moistened paper in its upper third, in the longitudinal direction, where the seeds were placed directing the micropyle down. The length of primary roots and seedlings considered as normal was determined at the end of the fifth day using a millimeter ruler.

In the experimental field, sowing was carried out in pits spaced $30 \mathrm{~cm}$ from each other with a density of ten seeds per pit. After emergence,thinning was performed to maintain four plants per pit. These pits were established in beds with dimensions of $6 \mathrm{~m}$ in length and $1 \mathrm{~m}$ in width filled with soil collected from the A1 horizon of a solodic eutrophic Planosol belonging to the Pelotas mapping unit. The fertilization was carried out according to the recommendations of Comissão de Fertilidade e Química do Solo - RS/SC (2016) by incorporating the nutrients to the soil five days before sowing.
The assessment of the performance of the plants produced from seeds of different levels of physiological quality and treated with an amino acid-based product was carried out during maturation in the four plants from each plot. Plant height, stem diameter, number of branches per plant, number of legumes and seeds per plant, one thousand seed weight, and seed productivity per plant were determined.

Stem diameter was measured just above the soil level with the use of a digital caliper and plant height was determined using a millimeter ruler. The number of branches was counted on the main stem. The number of legumes and seeds per plant was obtained by a direct counting. In order to determine the productivity per plant, the seeds harvested were weighedon a precision scale. All values were expressed as means of the four plants of each plot (pit).

After data collection and tabulation, the assumptions for the analysis of variance were verified. When these assumptions were met, the analysis of variance was performed at $5 \%$ probability.The means of the qualitative factor (physiological quality) were compared by the Tukey's test at $5 \%$ probability when the F-test was significant. For the quantitative factor (product doses), a polynomial regression analysis was performed, being tested up to the fourth degree of the polynomial.

\section{Results and Discussion}

According to the data of the physiological quality of seeds treated with amino acids (Table 1), the variables first germination count, accelerated aging, and cold test showed an interaction between the factors initial physiological quality of lots and seed treatment with amino acids. No interaction was observed between the factors germination and seedling growth.

The treatment of soybean seeds with amino acids had no significant effect on seed germination and seedling length, regardless of the physiological quality of seed lot. For these response variables, only differences between lots can be observed, which is an expected result due to the treatment used to obtain them. In the vigor assessments, a negative effect of seed treatment was identified with increasing doses of amino acids, especially for lots of lower physiological quality (Figure 1). The results of other studies suggest that chemical products (fungicides and polymers), when applied alone or in combination, may lead to a reduction in the physiological quality and survival of seedlings under certain situations due to the phytotoxicity effect (Pereira et al., 2007). A similar effect may occur with the application of amino acid-based products due to its high concentration close to the seed in the germitest paper roll used in the tests. However, high physiological quality 
seeds did not present a reduction for these variables as the dose of amino acids increased. Thus, high physiological quality seeds may be able to tolerate or overcome the likely phytotoxic effects caused by increasing doses of amino acids.

Considering the effects of different levels of physiological quality, the best physiological quality lot showed a superior behavior for all the physiological variables analyzed regardless of the treatment with amino acids, whereas the lower quality lot presented an inferior behavior (Table 1). According to Peske et al. (2012), high vigor seeds exhibit a superior performance when compared to low physiological quality seeds in quality tests conducted in the laboratory and in initial seedling growth tests, as well as their performance in the field (Schereen et al., 2010; Mattioni et al., 2012; Tavares et al., 2013).

Regarding the growth under field conditions, the variables plant height, number of branches per plant, and stem diameter did not show a significant effect of the interaction between factors and amino acid doses (Table 2). However, in isolation, the physiological quality of seeds influenced plant

Table 1. Germination, first germination count, accelerated aging, cold test, root and shoot length of soybean seeds of different levels of physiological quality treated with doses of amino acids.

\begin{tabular}{|c|c|c|c|c|c|c|}
\hline \multirow{2}{*}{ Physiological quality } & \multicolumn{5}{|c|}{ Doses of amino acids (mL. $100 \mathrm{~kg}^{-1}$ of seeds) } & \multirow{2}{*}{ Mean } \\
\hline & 0 & 200 & 400 & 600 & 800 & \\
\hline \multicolumn{7}{|c|}{ Germination (\%) } \\
\hline High & 93 & 90 & 96 & 96 & 98 & $94 \mathrm{~A}$ \\
\hline Intermediate & 91 & 91 & 92 & 91 & 92 & $91 \mathrm{~A}$ \\
\hline Low & 88 & 75 & 81 & 78 & 87 & $82 \mathrm{~B}$ \\
\hline Mean & $91^{\mathrm{ns}}$ & 85 & 90 & 88 & 92 & \\
\hline CV (\%) & & & & & & \\
\hline \multicolumn{7}{|c|}{ First germination count $(\%)$} \\
\hline High & $83 \mathrm{~A}$ & $80 \mathrm{~A}$ & $85 \mathrm{~A}$ & $86 \mathrm{~A}$ & $88 \mathrm{~A}$ & 84 \\
\hline Intermediate & $75 \mathrm{AB}$ & $75 \mathrm{~A}$ & $76 \mathrm{~A}$ & $70 \mathrm{~B}$ & $67 \mathrm{~B}$ & 73 \\
\hline Low & $68 \mathrm{~B}$ & $51 \mathrm{~B}$ & $64 \mathrm{~B}$ & $55 \mathrm{C}$ & $67 \mathrm{~B}$ & 61 \\
\hline Mean & 75 & 69 & 75 & 70 & 74 & \\
\hline CV (\%) & & & & & & \\
\hline \multicolumn{7}{|c|}{ Accelerated aging $(\%)$} \\
\hline High & $97 \mathrm{~A}$ & $94 \mathrm{~A}$ & $96 \mathrm{~A}$ & $93 \mathrm{~A}$ & $94 \mathrm{~A}$ & 95 \\
\hline Intermediate & $76 \mathrm{~B}$ & $75 \mathrm{~B}$ & $79 \mathrm{~B}$ & $63 \mathrm{~B}$ & $62 \mathrm{~B}$ & 71 \\
\hline Low & $57 \mathrm{C}$ & $54 \mathrm{C}$ & $48 \mathrm{C}$ & $36 \mathrm{C}$ & $49 \mathrm{C}$ & 49 \\
\hline Mean & 77 & 74 & 74 & 64 & 68 & \\
\hline CV (\%) & & & & & & \\
\hline \multicolumn{7}{|c|}{ Cold te } \\
\hline High & $97 \mathrm{~A}$ & $85 \mathrm{~A}$ & $90 \mathrm{~A}$ & $97 \mathrm{~A}$ & $94 \mathrm{~A}$ & 93 \\
\hline Intermediate & $70 \mathrm{~B}$ & $67 \mathrm{~B}$ & $65 \mathrm{~B}$ & $68 \mathrm{~B}$ & $54 \mathrm{~B}$ & 65 \\
\hline Low & $48 \mathrm{C}$ & $48 \mathrm{C}$ & $42 \mathrm{C}$ & $44 \mathrm{C}$ & $40 \mathrm{C}$ & 44 \\
\hline Mean & 72 & 67 & 66 & 70 & 63 & \\
\hline CV (\%) & & & & & & \\
\hline \multicolumn{7}{|c|}{ Shoot length (mm) } \\
\hline High & 89.0 & 95.3 & 89.2 & 93.3 & 88.6 & $91.1 \mathrm{~A}$ \\
\hline Intermediate & 75.1 & 74.3 & 75.0 & 75.2 & 72.4 & $74.4 \mathrm{~B}$ \\
\hline Low & 69.1 & 80.2 & 70.8 & 67.2 & 76.1 & $72.7 \mathrm{~B}$ \\
\hline Mean & $77.7^{\mathrm{ns}}$ & 83.3 & 78.3 & 78.6 & 79.0 & 79.4 \\
\hline CV (\%) & & & & & & \\
\hline \multicolumn{7}{|c|}{ Root length (mm) } \\
\hline High & 136.4 & 137.4 & 140.2 & 145.5 & 143.7 & $140.7 \mathrm{~A}$ \\
\hline Intermediate & 130.2 & 131.0 & 131.2 & 123.7 & 127.6 & $128.7 \mathrm{~B}$ \\
\hline Low & 121.6 & 114.0 & 112.9 & 99.2 & 117.6 & $113.1 \mathrm{C}$ \\
\hline Mean & $129.4^{\mathrm{ns}}$ & 127.5 & 128.1 & 122.8 & 129.6 & 127.5 \\
\hline CV (\%) & \multicolumn{6}{|c|}{8.28} \\
\hline
\end{tabular}

Means followed by the same uppercase letter in the column do not differ from each other by the Tukey's test at $5 \%$ probability error. CV - coefficient of variation; ns - not significant. 

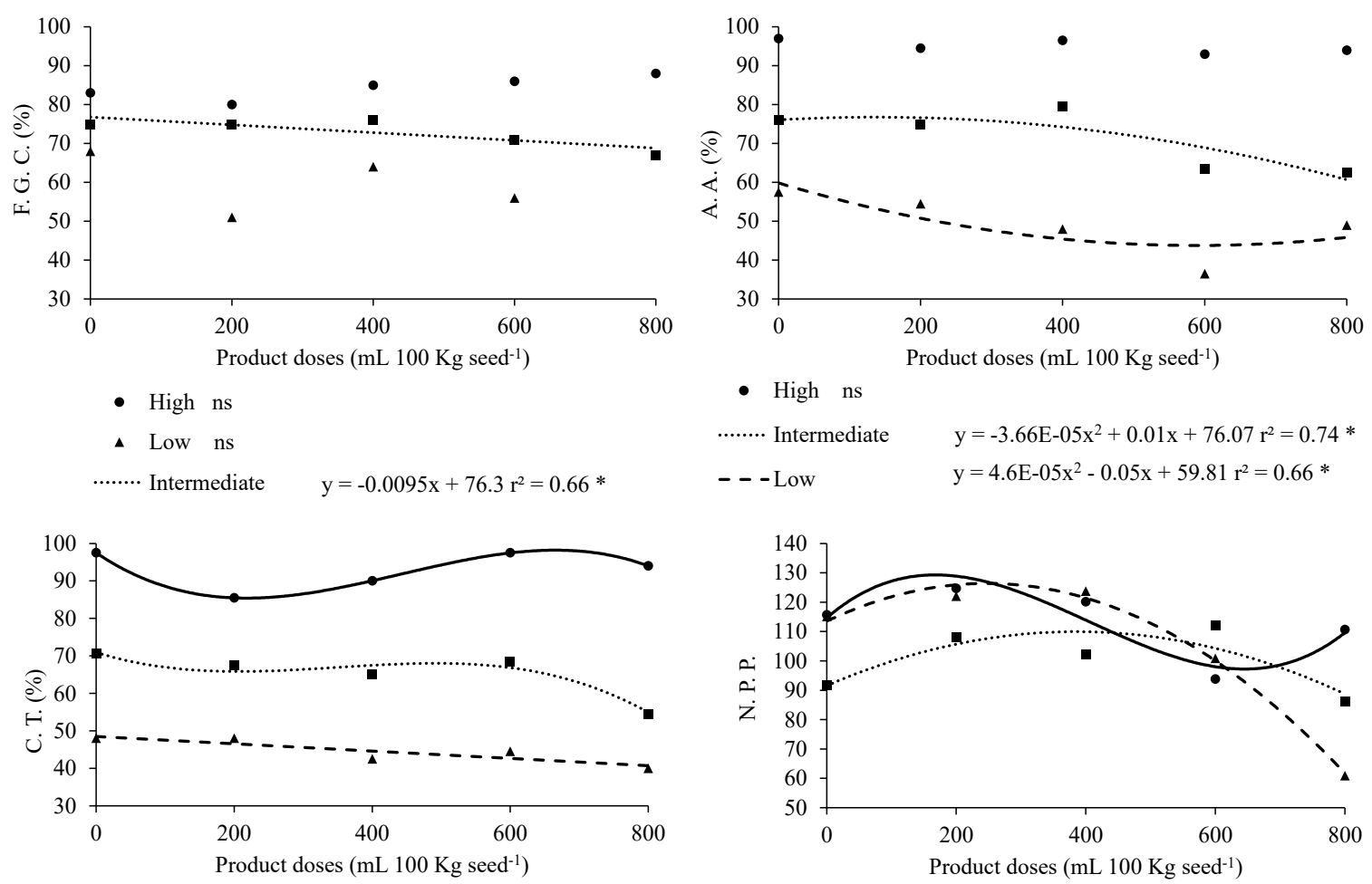

$\begin{array}{ll}\text { - High } & y=-3 E-07 x^{3}+0.0004 x^{2}-0.12 x+97.5 r^{2}=0.99 * \\ \text { ….... Intermediate } & y=-1,9 E-07 x^{3}+0.0002 x^{2}-0.06 x+70.9 r^{2}=0.92 \\ -- \text { - Low } & y=-0.0098 x+48.5 r^{2}=0.78 *\end{array}$

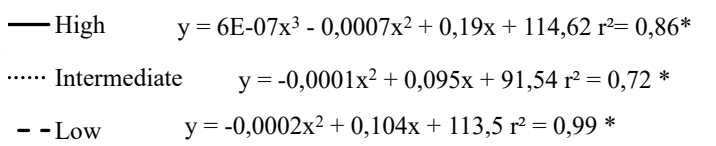

Figure 1. First germination count (FGC), accelerated aging (AA), cold test (CT), and number of pods per plant (NPP) of soybean seeds of different levels of physiological quality treated with doses of amino acids. ns- not significant.

Table 2. Stem diameter, plant height, and number of branches per plant from soybean seeds of different levels of physiological quality treated with doses of amino acids.

\begin{tabular}{|c|c|c|c|c|c|c|}
\hline \multirow{2}{*}{ Physiological quality } & \multicolumn{5}{|c|}{ Doses of amino acids (mL. $100 \mathrm{~kg}^{-1}$ of seeds) } & \multirow{2}{*}{ Mean } \\
\hline & 0 & 200 & 400 & 600 & 800 & \\
\hline \multicolumn{7}{|c|}{ Stem diameter $(\mathrm{mm})$} \\
\hline High & $10.01^{\mathrm{ns}}$ & 9.44 & 9.03 & 8.05 & 8.78 & 9.06 \\
\hline Intermediate & 8.35 & 9.45 & 9.67 & 9.92 & 9.61 & 9.40 \\
\hline Low & 9.65 & 9.95 & 9.66 & 8.40 & 9.39 & 9.41 \\
\hline Mean & 9.34 & 9.61 & 9.45 & 8.79 & 9.26 & \\
\hline CV $(\%)$ & & & & & & \\
\hline \multicolumn{7}{|c|}{ Plant height $(\mathrm{cm})$} \\
\hline High & 114.46 & 118.58 & 118.75 & 117.28 & 116.38 & $117.0 \mathrm{~A}$ \\
\hline Intermediate & 120.0 & 115.25 & 111.58 & 112.32 & 111.88 & $114.2 \mathrm{~B}$ \\
\hline Low & 116.42 & 113.25 & 112.25 & 110.47 & 111.25 & $112.7 \mathrm{~B}$ \\
\hline Mean & $116.96^{\text {ns }}$ & 115.69 & 114.19 & 113.36 & 113.17 & \\
\hline CV (\%) & & & & & & \\
\hline \multicolumn{7}{|c|}{ Number of branches per plant } \\
\hline High & $7.3^{\mathrm{ns}}$ & 8.7 & 7.2 & 7.3 & 7.6 & 7.6 \\
\hline Intermediate & 7.7 & 8.0 & 7.2 & 6.9 & 7.8 & 7.5 \\
\hline Low & 7.3 & 8.2 & 6.6 & 6.2 & 7.2 & 7.1 \\
\hline Mean & 7.4 & 8.3 & 7.0 & 6.8 & 7.5 & \\
\hline CV (\%) & \multicolumn{6}{|c|}{17.64} \\
\hline
\end{tabular}

Means followed by the same uppercase letter in the column do not differ from each other by the Tukey's test at $5 \%$ probability error. CV - coefficient of variation; ns - not significant. 
height and soybean plants from high physiological quality seeds showed a higher height at the end of the cycle. This is in accordance with the assumption that high physiological quality seeds originate from plants of higher initial growth in leaf area, dry matter, and plant height, thus presenting a higher photosynthetic surface, which results in higher plants at the end of the higher cycle (Kolchinski et al., 2006, Silva et al., 2013).

No effect of the physiological quality of seed was observed on stem diameter and number of branches per plant. These results differ from those found by Silva et al. (2013), who observed that plants from seeds of a higher physiological quality have a higher stem diameter and number of branches per plant.

No significant interaction was identified between yield components and the number of seeds per plant, one thousand seed weight, and grain productivity (Table 3 ). A significant interaction of the number of pods per plant was only identified between the factors (Figure 2), which was the only response variable that showed an effect for seed treatment with amino acids in the performance of plants in the field.

In general, plants from seeds of the different levels of physiological quality presented an increase in the number of pods per plant at a dose of $200 \mathrm{~mL} .100 \mathrm{~kg}^{-1}$ of seeds, with significant reductions with different intensities later. This result may be a reflection of the vigor of treated seeds, which also presented reductions as the amino acid dose increased since the vigor of soybean seeds used in the sowing had a significant effect on the number of pods per plant (Silva et al., 2013). In addition, an isolated effect of the physiological quality of seeds was observed on the number of pods per plant, which could be observed at the zero dose of amino acids since plants from high physiological quality seeds presented a higher number of pods when compared to those with a lower vigor.

The number of pods per plant is a yield component of extreme importance and has been cited by other authors as the main responsible for increasing yield (Silva et al., 2013; Tavares et al., 2013). However, in this study, the variation in the number of pods per plant, due to the treatment with amino acids, did not reflect in variations of productivity per plant. Santos et al. (2014) worked with soybeans and observed that biostimulants containing amino acids provided increases in leaf dry matter, stem dry matter, pod dry matter, and leaf area, both in seed and leaf applications.

Table 3. Number of pods and seeds, one thousand seed weight, and productivity of plants from soybean seeds of different levels of physiological quality treated with doses of amino acids.

\begin{tabular}{|c|c|c|c|c|c|c|}
\hline \multirow{2}{*}{ Physiological quality } & \multicolumn{5}{|c|}{ Doses of amino acids (mL. $100 \mathrm{~kg}^{-1}$ of seeds) } & \multirow{2}{*}{ Mean } \\
\hline & 0 & 200 & 400 & 600 & 800 & \\
\hline \multicolumn{7}{|c|}{ Number of pods per plant } \\
\hline High & $116 \mathrm{~A}$ & $125 \mathrm{~A}$ & $120 \mathrm{~A}$ & $99 \mathrm{~A}$ & $111 \mathrm{~A}$ & 114 \\
\hline Intermediate & $92 \mathrm{~B}$ & $108 \mathrm{~A}$ & $102 \mathrm{~A}$ & $112 \mathrm{~A}$ & $86 \mathrm{~B}$ & 100 \\
\hline Low & $115 \mathrm{AB}$ & $122 \mathrm{~A}$ & $124 \mathrm{~A}$ & $101 \mathrm{~A}$ & $61 \mathrm{C}$ & 105 \\
\hline Mean & 108 & 118 & 115 & 102 & 89 & \\
\hline CV (\%) & & & & & & \\
\hline \multicolumn{7}{|c|}{ Number of seeds per plant } \\
\hline High & $270^{\mathrm{ns}}$ & 260 & 225 & 203 & 260 & 243 \\
\hline Intermediate & 227 & 234 & 228 & 251 & 263 & 240 \\
\hline Low & 262 & 241 & 219 & 202 & 211 & 227 \\
\hline Mean & 253 & 245 & 224 & 219 & 245 & \\
\hline CV (\%) & & & & & & \\
\hline \multicolumn{7}{|c|}{ One thousand seed weight } \\
\hline High & $149.52^{\text {ns }}$ & 144.54 & 145.98 & 134.54 & 140.35 & 143.0 \\
\hline Intermediate & 135.20 & 139.87 & 147.45 & 145.77 & 145.29 & 142.7 \\
\hline Low & 148.76 & 148.67 & 145.99 & 135.23 & 134.04 & 142.5 \\
\hline Mean & 144.49 & 144.36 & 146.47 & 138.51 & 139.89 & \\
\hline CV (\%) & & & & & & \\
\hline \multicolumn{7}{|c|}{ Productivity (g. plant ${ }^{-1}$ ) } \\
\hline High & 34.55 & 34.16 & 32.42 & 31.71 & 33.46 & $33.26 \mathrm{~A}$ \\
\hline Intermediate & 32.25 & 31.45 & 31.79 & 30.54 & 30.82 & $31.37 \mathrm{~A}$ \\
\hline Low & 28.74 & 28.57 & 28.21 & 28.18 & 27.69 & $28.28 \mathrm{~B}$ \\
\hline Mean & $31.85^{\mathrm{ns}}$ & 31.39 & 30.81 & 30.14 & 30.66 & \\
\hline CV (\%) & \multicolumn{6}{|c|}{9.60} \\
\hline
\end{tabular}

Means followed by the same uppercase letter in the column do not differ from each other by the Tukey's test at 5\% probability error. CV - coefficient of variation; ns - not significant. 
No effect was observed between the number of seeds per plant and seed treatment with amino acids northe physiological quality of seeds used in the sowing. The same results were also found for one thousand seed weight. Silva et al. (2013) observed that plants from high physiological quality seeds had a higher number of seeds per plant, thus differing from the results of our study. However, in relation to the one thousand seed weight, they also did not observe an effect of the quality of the seed used in the sowing process.

Seed treatment with amino acids did not promote plant growth nor yield components, and thus, its effect on soybean productivity was not detected. In general, the use of amino acids via seed treatment did not affect the performance in the field regardless of the physiological quality of seeds. Zobiole et al. (2010) observed a positive effect of the application of amino acids on the photosynthetic performance of soybean plants that suffered injuries due to glyphosate application and concluded that amino acids, which are precursors of plant hormones, promoted a better balance in plant metabolism. However, when the application of amino acids was performed on healthy soybean plants, they did not detect a significant effect on their photosynthetic performance.These authors suggest that when the application of amino acids is carried out in isolation in healthy plants, they do not present significant effects because there is a concept similar to that of sufficiency level used in plant nutrition in which below a certain level plants respond to the application amino acids and above this level there is no response. Possibly, the seed lot used in this experiment did not present amino acid deficiency in its composition and, therefore, it did not respond to the application of amino acids via seed treatment, even after accelerated aging.

However, the physiological quality of soybean seeds used in the sowing process had a significant influence on plant productivity (Table 3 ). Plants from high physiological quality seeds produced approximately $15 \%$ more than plants from low physiological quality seeds. This result is mainly due to changes that the use of high physiological quality seeds promotes in all processes of growth and development of plants. The use of high physiological quality seeds is extremely important for the implantation of cultivation fields with a higher productive potential (Silva et al., 2013; Tavares et al., 2013; Cantarelli et al., 2015).

The effect of the physiological quality of seeds can be identified in the implantation of the cultivation fields, in which high physiological quality seeds provide a higher seedling emergence rate and a plant stand density (Schereen et al., 2010). However, differences in the productivity of cultivation fields due to the physiological quality of seeds are not related only to plant stand density. Our results, together with other studies in the literature, confirm that plants from seed lots of a high physiological quality have a higher productive ability (Tavares et al., 2013; Silva et al., 2013). These differences are identified early in the development and growth of soybean crop because plants from high physiological quality seeds have a higher growth rate, leaf area, and dry matter production (Kolchinski et al., 2006). Another relevant aspect to be addressed when studying the physiological quality of seeds is a higher variability among plants that occur in a cultivation field formed from seeds of a low physiological quality (Cantarelli et al., 2015), which implies in a greater difficulty to manage the crop and less efficient cultural practices. Therefore, the use of high physiological quality seeds is a crucial input for the formation of more productive crops, regardless of the species to be cultivated (Melo et al., 2006; Schereen et al., 2010; Silva et al., 2013; Mattioni et al., 2012; Tavares et al., 2013).

Thus, in general, the initial hypothesis that the treatment with amino acids in low physiological quality seeds would promote a better physiological performance of soybean seeds and plants under field conditions, resulting in higher productivity, is rejected.

\section{Conclusions}

Seed treatment with amino acids does not promote increases in the physiological performance of seeds and plants nor in productivity.

The productivity of isolated soybean plants from seed lots of a high physiological quality is $15 \%$ higher than that of plants from seed lots of a low physiological quality.

\section{References}

ABRECHT, L.P.; BAZO, G.L.; DEMENECK-VIEIRA, P.V.; ALBRECHT, A.J.P.; BRACCINI, A.L. Desempenho fisiológico das sementes de ervilha tratadas com biorregulador. Comunicata Scientiae, v.5, n.4, p.464-470, 2014. https://comunicatascientiae.com. $\mathrm{br} /$ comunicata/article/view/350/0

BETTONI, M.M.; FABBRIN, E.G.S.; OLINIK, J.R.; MÓGOR, Á.F. Efeito da aplicação foliar de hidrolisado protéico sob a produtividade de cultivares de brócolis. RevistaAgro@mbiente On-line, v.7, n.2, p.179-183, 2013. https://revista.ufrr.br/agroambiente/article/view/943

BRASIL. Ministério da Agricultura, Pecuária e Abastecimento. Regras para análise de sementes.Ministério da Agricultura, Pecuária e Abastecimento. Secretaria de Defesa Agropecuária. Brasília: MAPA/ACS, 2009. 395p.

BRZEZINSKI, C.R.; HENNING, A.A.; ABATI, J.; HENNING, F.A.; FRANÇA-NETO, J.B.; KRYZANOWSKI, F.C.; ZUCARELI, C. Épocas de tratamento de sementes no estabelecimento e desempenho produtivo da cultura da soja. Journal of Seed Science, v.37, n.2, p.147-153, 2015. http://submission.scielo.br/index.php/jss/ article/view/148363 
CANTARELLI, L.D.; SCHUCH, L.O.B.; RUFINO, C.A.; TAVARES, L.C.; VIEIRA, J.F. Physiological seeds quality: spatial distribution and variability among soybean plant population. Bioscience Journal, v.31, n.2, p.344-351, 2015. http://www.seer.ufu. br/index.php/biosciencejournal/article/view/22274

CÍCERO, S.M.; VIEIRA, R.D. Teste de frio. In: VIEIRA, R.D.; CARVALHO, N.M. Testes de vigor em sementes. Jaboticabal: FUNEP, 1994. p.151-164.

COMISSÃO DE QUÍMICA E FERTILIDADE DO SOLO - RS/SC. Manual de Adubação e de Calagem para os estados do Rio Grande do Sul e de Santa Catarina. $11^{\circ}$ ed. Porto Alegre: NRS/SBCS, 2016. 400p.

CUNHA, R.P.; CORREA, M.F.; SCHUCH, L.O.B.; OLIVEIRA, R.C.; ABREU JUNIOR, J.S.; SILVA, J.D.G.; ALMEIDA, T.L. Diferentes tratamentos de sementes sobre o desenvolvimento de plantas de soja. Ciência Rural, v.45, n.10, 2015. http://www.scielo. br/pdf/cr/2015nahead/0103-8478-cr-cr20140742.pdf

HAMMAD, S.A.R.; ALI, O.A.M. Physiological and biochemical studies on drought tolerance of wheat plants by application of amino acids and yeast extract. Annals of Agricultural Science, v.59, n.1, p.133-145, 2014. https://www.sciencedirect.com/science/article/pii/ S0570178314000190

HILDEBRANDT, T.M.; NESI, A.N.; ARAÚJO, W.L.; BRAUN, H.P. Amino acid catabolism in plants. Molecular Plant, v.8, p.15631579, 2015. https://www.ncbi.nlm.nih.gov/pubmed/26384576

KOLCHINSKI, E.M.; SCHUCH, L.O.B.; PESKE, S.T. Crescimento inicial de soja em função do vigor das sementes. Revista Brasileira de Agrociência, v.12, n. 2, p.163-166, 2006. https://periodicos.ufpel. edu.br/ojs2/index.php/CAST/article/view/4513/3377

KOLLING, D.F.; SANGOI, L.; SOUZA, C.A.; SCHENATTO, D.E.; GIORDANI, W.; BONIATTI, C.M. Tratamento de sementes com bioestimulante ao milho submetido a diferentes variabilidades na distribuição espacial das plantas. Ciência Rural, v.46, n.2, p.248-253, 2016. http://www.scielo.br/pdf/cr/v46n2/1678-4596-cr-46-02-00248.pdf

LUDWIG, M.P.; FILHO, O.A.L.; BAUDET, L.; DUTRA, L.M.C.; AVELAR, S.A.G.; CRIZEL, R.L. Qualidade de sementes de soja armazenadas após recobrimento com aminoácido, polímero, fungicida e inseticida. Revista Brasileira de Sementes, v.33, n.3, p.395-406, 2011. http://www.scielo.br/pdf/rbs/v33n3/02.pdf

MARCOS-FILHO, J. Teste de envelhecimento acelerado. In: KRZYZANOWSKI, F.C.; VIEIRA, R.D.; FRANÇA-NETO, J.B. (Ed.) Vigor de sementes: conceitos e testes. Londrina: ABRATES, 1999. p.1-24.

MATTIONI, F.; ALBUQUERQUE, M.C.F.; MARCOS-FILHO, J.; GUIMARÃES, S.C. Vigor de sementes e desempenho agronômico de plantas de algodão. Revista Brasileira de Sementes, v.34, n.1, p.108-116, 2012. http://www.scielo.br/pdf/rbs/v34n1/a14v34n1.pdf

MELO, P.T.S.; SCHUCH, L.O.B.; ASSIS, F.N.; CONCENÇO, G. Comportamento individual de plantas originadas de sementes com diferentes níveis de qualidade fisiológica em populações de arroz irrigado. Revista Brasileira de Sementes, v.28, n.2, p.84-94, 2006. http://www.scielo.br/pdf/rbs/v28n2/a11v28n2.pdf
MELO, D.; BRANDÃO, W.T.M.; NÓBREGA, L.H.P.; WERNKE, I. Qualidade de sementes de soja convencional e RoundupReady (RR), produzida para consumo próprio e comercial. Revista de Ciências Agrárias, v.39, n.2, p.300-309, 2016. http://www.scielo.mec.pt/pdf/ $\mathrm{rca} / \mathrm{v} 39 \mathrm{n} 2 / \mathrm{v} 39 \mathrm{n} 2 \mathrm{a} 13 . \mathrm{pdf}$

MONDAL, M.F.; ASADUZZAMAN, M.; TANAKA, H.; ASAO, T. Effects of amino acids on the growth and flowering of Eustoma grandiflorum under autotoxicity in closed hydroponic culture. Scientia Horticulturae, v.192, p.453-459, 2015. https://www. sciencedirect.com/science/article/pii/S0304423815300133

NAKAGAWA, J. Testes de vigor baseados na avaliação de plântulas. In: KRZYZANOWSKI, F.C.; VIEIRA, R.D.; FRANÇA-NETO, J.B. (Ed.).Vigor de sementes: conceitos e testes. Londrina: ABRATES, 1999. p.1-21.

PEREIRA， C.E.; OLIVEIRA， J.A.; EVANGELISTA， J.R.E.; BOTELHO, F.J.E.; OLIVEIRA, G.E.; TRENTINI, P. Desempenho de sementes de soja tratadas com fungicidas e peliculizadas durante o armazenamento. Ciência e Agrotecnologia, v.31, p.656-665, 2007. http://www.scielo.br/pdf/cagro/v31n3/a09v31n3.pdf

PESKE, S.T.; VILlELA, F.A.; MENEGHELlO, G.E. Sementes: Fundamentos Científicos e Tecnológicos. $2^{\circ}$ ed. Pelotas: UFPel, 2012. 573p.

SANTOS, V.M.; MELO, A.V.; CARDOSO, D.P.; SILVA, A.R.; BENÍCIO, L.P.F.; FERREIRA, E.A. Desenvolvimento de plantas de soja em função de bioestimulantes em condições de adubação fosfatada. Bioscience Journal, v.30, n.4, p.1087-1094, 2014. http:// www.seer.ufu.br/index.php/biosciencejournal/article/view/18184

SCHEREEN, B.R.; PESKE, S.T.; SCHUCH, L.O.B.; BARROS, A.C.S.A. Qualidade fisiológica e produtividade de sementes de soja. Revista Brasileira de Sementes, v.32, n.3, p.035-041, 2010. http:// www.scielo.br/pdf/rbs/v32n3/v32n3a04.pdf

SILVA, C.S.; SCHUCH, L.O.B.; OLIVO, M.; SEUS, R. Desempenho de plantas isoladas de soja, biometria e qualidade fisiológica das sementes. Revista da Faculdade de Zootecnia, Veterinária e Agronomia, v.19, n.1, p.1-9, 2013. http://revistaseletronicas.pucrs. br/ojs/index.php/fzva/article/view/10305

TAIZ, L.; ZEIGER, E. Fisiologia Vegetal. 5a edição, Artmed. 2013. 782p.

TAVARES, L.C.; RUFINO, C.A.; BRUNES, A.P.; TUNES, L.M.; BARROS, A.C.S.A.; PESKE, S.T. Desempenho de sementes de soja sob deficiência hídrica: rendimento e qualidade fisiológica da geração F1. Ciência Rural, v.43, n.8, p.1357-1363, 2013. http:// www.scielo.br/pdf/cr/v43n8/a22213cr2012-0950.pdf

WANG, J.; LIU, Z.; WANG, Y.; CHENG, W.; MOU, H. Production of a water soluble fertilizer containing amino acids by solid-state fermentation of soybean meal and evaluation of its efficacy on the rapeseed growth. Journal of Biotechnology, v.187, p.34-42, 2014. https://www.ncbi.nlm.nih.gov/pubmed/25062659

ZOBIOLE, L.H.S.; OLIVEIRA, R.S.; CONSTANTIN, J.; BIFFE, D.F. Prevenção de injúrias causadas por glyphosate em soja RR por meio do uso de aminoácido. Planta Daninha, v.29, n.1, p.195-205, 2010. http://www.scielo.br/scielo.php?script=sci_abstract\&pi$\mathrm{d}=\mathrm{S} 010083582011000100022 \& \operatorname{lng}=\mathrm{pt} \& \mathrm{nrm}=$ iso \& $\overline{\ln } \mathrm{n}=\mathrm{pt}$ 